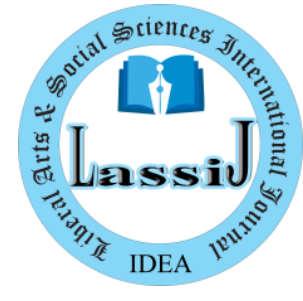

ISSN: 2664-8148 (Online)

Liberal Arts and Social Sciences

International Journal (LASSIJ)

https://doi.org/10.47264/idea.lassij/2.2.4

Vol. 2, No. 2, (July-December) 2018, 29-41

https://www.ideapublishers.org/lassij

\title{
Islamic Universalism and the Nation State
}

\author{
Manzoor Ahmad Naazer*
}

Department of Politics and International Relations, International Islamic University, Islamabad Pakistan.

\begin{abstract}
This study explores the legitimacy of the nation-states in the light of Islamic teachings, and the thoughts of prominent Muslim jurists. The research focuses on the questions, does Islam prescribe a specific form of the government; if a single unified state across the world is required as per the injunctions of Islam; does Islam outlaws the nationalism; does Islam commend a unitary or a federal state. The research investigates the state-formation process in the light of teachings of Quran and Sunnah of the Holy Prophet (PBUH) as well as writings of Muslim theologians and jurists. The nature of the state practiced in the Muslim world, the importance of Caliph and its actual role, place of tribalism and nationalism in Islam, are the main points of discussion. The study employs historical and descriptive methods and relies on secondary sources mainly books and articles covering writings of Muslim scholars from later generations.
\end{abstract}

Keywords: Islam, nationalism, nation-state, Madinah, government, caliph, monarchy, federal.

\section{Introduction}

Islam is a universal religion that does not believe in prejudices on geographical, racial, ethnic, or linguistic basis. The only virtue that Islam recognizes is piety (Taqwa) and there is no superiority of Arabs over non-Arabs and of whites over blacks and the vice versa. According to various Islamic injunctions and traditions narrated from the Holy Prophet, all the Muslims are brethren in Islam, and they are like the parts of a body. When a part of the body is in pain, other parts of the body also feel it. Muslims resemble bricks in a wall which reinforce and support each other. They are like the fingers of a hand when united together become the strength of the fist. The unity of the Muslims is must for their very existence, propagation of Allah's Message and for the enforcement of Divine Law in the world. Despite these Islamic injunctions, the political map of the contemporary world depicts splits among the Muslims.

Muslims live in all parts of the world. Though they are a single Ummah (nation) they are politically divided into scores of sovereign states including 58 members of the Organization of Islamic Conference, now renamed as Organization of Islamic Cooperation (OIC), a representative body of 
the Muslim states. According to Pew Research Centre (2009), among OIC members only 50 are Muslim majority states. Besides, about one-fifth of the Muslims live as religious minorities in several other countries, including India, Ethiopia, China, Russia, and Tanzania - the five states with largest Muslim minority population. Muslims living as minorities in a few parts of the world struggle to create their own independent states, such as in Thailand, the Philippines, Myanmar, Chechnya, and East Turkistan, etc.

The nation-states are the hallmarks and constituent units of present international system of which the Muslim world is an important part. The existence of scores of small and weak nation-states in the Muslim world sparks a debate about utility as well as the legitimacy of the modern nationstates in the Muslim world. The nation-states are criticized for three reasons. First, the Muslim world has been divided on a territorial basis, which has undermined Islamic unity, weakened Muslims, and exposed them to the exploitation and aggression of the enemies of Islam. Second, nation-states are formed based on territorial nationalism which not only has no place in Islamic teachings, but it also contradicts the idea of Islamic universalism. Third, nationalism, associated with the concept of the nation-state, is a secular Western ideology that depoliticized Islam and prevented enforcement of Shariah in the Muslim World.

The pessimistic view of the nation-states among the Muslims, particularly, its religious community raises misgivings about merit and the very foundation of these states. It is, therefore, imperative to explore the legitimacy of nation-states, in the light of Islamic teachings, and thoughts of selected prominent Muslim jurists. The present study explores, does Islam prescribe a specific form of government; if a single unified state is required as per injunctions of Islam; does Islam outlaw nationalism; does Islam commend a unitary or a federal state.

\section{Literature Review}

Much has been spoken and written for and against the nation-state. The existing literature takes only one side of the picture. The scholars who write in favour of nation-states mostly rely on secular or western sources. For instance, Tibi (1997) attributes rise of nationalism and consequent emergence of nation-states as an outcome of domestic socio-political factors in the Ottoman Empire and internationalization of international system. The supporters of Islamic universalism use all force to negate the idea of nation-state calling it a western idea which violates Islamic concept of universal brotherhood.

Though the nation-state is the reality of the time, it is viewed as a source of divisions in the Muslim world as well as a conspiracy against Islam itself (Khan, 1964-c: pp. 45-8). As the idea of the nation-state is very much affiliated with the concept of nationalism, its existence is, therefore, also regarded as a negation of Islamic universalism. The presence of nation-states is viewed as an obstacle to the unity of Ummah as well as the implementation of Shariah, for which a Caliph is thought to be essential as a protector of faith and the enforcer of Divine Law (Ahsan, 1964: pp. 34-5; Khan, 1964-b: pp. 77-9; Ghuman, 2013: pp. 25-38). It is said that nationalism, as an imported idea from the West, brought benefits as well as injuries to the Islamic world. The challenge of separation of politics and religion has confronted the traditional Muslim thinking at large. Moreover, the question of whether sovereignty rests with God or the people also confronts the 
Muslim scholars. Is there a chance of reconciliation between the two in the backdrop of the modern state system, is still debated (Rosenthal, 1965: p. 6)? Thus, the Islamic World is confronted with two opposite concepts, i.e., the legitimacy of the nation-state which came into being on the Western ideas of nationalism and the revival of Islamic universalism which negates all ethnic, linguistic, racial and territorial divisions (Tibi, 1997: p. 220).

This study endeavours to explore legitimacy of nation-state in the light of teachings of Islam. It takes a critical view of the political thoughts of earlier Muslim philosophers who built theories to legitimize despotic rule of that times based on which contemporary critics take hard line against nation-states in the Muslim world. This study elucidates that Islam neither negates nationalism nor prohibit creation of nation-states.

\section{Research Methodology}

The present research is qualitative employing historical method. It relies mostly on secondary sources such as books and research articles. In some cases, texts from the Holy Quran and Hadiths of the Holy Prophet (PBUH) have also been used. The research takes a critical view of the political thoughts of conventional or orthodox Muslim scholars and religious leadership. It endeavours to present a counter narrative that legitimizes political map of contemporary Muslim world. To augment the arguments, selective writings of Muslim scholars from later generations have been used. The research investigates the state-formation process in the light of narrations of Quran and Sunnah as well as theologians and jurists. The form and structure of the state, as well as its essentials, are discussed shortly. The nature of the state practiced in the Muslim world, the importance of Caliph and its actual role, place of tribalism and nationalism in Islam, are the main points of discussion.

\section{Discussion and Findings}

\subsection{Islam and the Structure of State}

The Quran does not prescribe any fixed form of government system or structure of the state. It only provides a spiritual perspective in which the operations of government are conducted. Brohi (1982) precisely noted that a religion that is universal and "valid for all epochs" could not very well give us a fixed formula for formation of the state structure or the government design. As Islam is a dynamic and progressive religion which is for all times and all people, therefore, it left the door open for the believers to adopt any system or form of government which is need of the time and which fulfils its universal objectives (pp. 78-80). This very fact has been eloquently summed up by Ibn Taymiyyah in these words: "any form of government where the authority of the Shariah is supreme is the required Islamic state" (Khan, 1973: p. 63). Ayubi (1991, p. 8) contends that Muslims formed their states and developed rule "through innovation, improvisation, and borrowing." The major political concepts were developed only when the political institutions were declining and the power of the rulers deteriorating. The theorizing of the institutions of caliphate took place when Abbasid dynasty confronted rival forces and growing opposition from Shi'ites, Kharijites, and others. 


\subsubsection{The Caliphate or the Monarchy: Myth and Reality}

The Holy Book only uses the words like Khalifah, Khalaif and other politically charged terms as references to the possible political power of Muslims in different contexts, but Quran and Sunnah are equally silent and do not prescribe any pattern to organize the state. Abu Bakr Siddique, the first of the four righteously guided caliphs, declared himself as a Khalifa-tur-Rasulullah. Hence, the Islamic state was known as a Khilafah (caliphate) which was governed purely in accordance with the teachings of Holy Quran and Sunnah of the Prophet Mohammad (PBUH). Islamic Law (Shariah) was the supreme law of the state. On this ground, several earlier Muslim jurists presented theories of Immamah or caliphate positing this institution as the requirement of Shariah. They also projected caliph as a protector or defender of Islamic faith and prescribed pre-requisites or essential conditions of an ideal Imam/caliph (Chaudhry, 1996: pp. 48-50 and 338-9)

The Muslim jurists of later generations, however, disputed with this view and they highlighted shortcomings of the theory and (actual) institution of caliphate. They noted that there existed a stark difference between theory and practice. With the passage of time, they maintained, the caliphate was transformed into a monarchy. Several Muslim scholars including Ibn Taymiyyah, Ibn Khaldun, Abul Kalam Azad, Jamaluddin Afghani and Maududi held this view (Haq 1991: pp. 168-9; Ayubi, 1991: p. 17; Ahmad, 1970: pp. 67-8). For instance, Maududi noted that the Islamic state established in Madinah by the Holy Prophet remained on the same pattern up to the first five years of the Caliphate of Hazrat Uthman. Henceforth, ignorance found its way into the Islamic social system and evil forces could not be checked. Hazrat Ali did his best to curb threats to the supremacy of the Islamic political system but even his blood could not stop the replacement of Islamic state with tyrant kingdom. He says, "Atheism grabbed power and authority in the name of the caliphate but, in reality, it was monarchy which was the very anti-thesis of Islam." He maintained, "the title of "God's reflection on the earth was invented for the kings, and they... assumed the position of absolute authority with all its implications." People made this a basis for king-worship which was against the intentions and teachings of the Holy Prophet (Maududi, 1981: pp. 26-9).

Ibn Khaldun asserted that Caliphate was transformed into mulk (monarchy) after the period of Khulafa-e-Rashideen. However, Shariah was retained with preservation of the outward form of the caliphate. The characteristics of the state, more or less, remained same during the period of Umayyads and even initial period of Abbasids up to the days of Harun al-Rashid and some of his sons. After this, nothing except the name of caliphate remained the same and the form of the state was completely changed into an absolute monarchy analogous to those ruled by the ancient Persian rulers. These monarchies were formed by the force of asabiyya of tribes. But just after two or three generations, the force of asabiyya of the clans and tribes vanished and kings were to rule with force of the sword. The rulers used to live luxurious lives becoming oppressive for the people and causing hatred and discontent among them. Ultimately, the dynasties were to be taken over by more powerful and cohesive tribes (Haq, 1991: pp. 168-9).

Due to these hard realities, Ibn Taymiyyah did neither endorse the theory of Immamah / caliphate nor laid down conditions of an idea caliph. He asserted that only the enforcement of Shariah and justice was the indispensable feature of an Islamic state. He endorsed the idea, "Allah helps the 
just government even if it is infidel and does not help the tyrannical government even if it is Muslim." For him, the Imamah or caliphate is not a pillar of Islam but only a minor or a secondary issue. The idea of the infallibility of the Imam or Caliph does also not convince him. For him, infallibility of Ummah is independent of the infallibility of ruler/leader. He holds that the form and structure of the state is not so important but the enforcement of Shariah should be the primary objective (Khan, 1973: pp. 23-48). Meanwhile, it is imperative to study the internal structure of the Muslim dynasties, the so-called Islamic caliphates as well as the place of Shariah in them. It will help understand their true nature and find the gap in theory and practice or most appropriately the myth and the reality of Islamic caliphate in historical perspective.

It has been discussed earlier that the caliphate was transformed into monarchy after the period of Khulafa-e-Rashideen. The latter were elevated to their positions by the consent of the Muslim community living in Madinah signifying a limited form of direct democracy, though the modes of their election varied. After the period of Khulafa-e-Rashideen, hereditary rule found its way into the Islamic political system, thus, monarchy practically replaced the caliphate. However, Shariah was retained with preservation of the outward form of the caliphate. The characteristics of the state, more or less, remained the same during the period of Umayyads and even initial period of Abbasids up to the days of Harun al-Rashid and some of his successors. Hereinafter, nothing except the name of the caliphate remained the same. The rulers, the co-called caliphs, lived luxurious lives becoming oppressive for the people and causing discontent among them. Ultimately, the power and legitimacy of the dynasties were challenged by the rising opposing groups who threatened their existence of them. At this moment, the jurists came to rescue them, theorizing the ideal state under a single caliph who to be a protector of the faith. They tried to mix the idealism of the Greek philosophers with Islamic teachings fitting in them political institutions of the time in them. The jurists were, in fact, state functionaries, receiving a regular stipend and striving to get legitimacy for the rulers (Haq 1991: pp. 168-9; Ahmad, 1970: 67-8; Sherwani, 1997: pp. 89-91).

Those who refused to play in the hands of despotic rulers, like Imam Abu Hanifa, Imam Malik, and Ibn Taymiyyah were persecuted and physically tortured. What has been said relates to the period prior to the fall of Baghdad. The history of caliphates formed later including Ottoman caliphate is no more different. After the fall of Baghdad, and revival of the caliphate in Egypt by the Mamlukes, the Caliph had become almost a non-entity, enjoying "absolutely no authority, influence, dignity or respect from the public." Tibi noted that during the last days of the Abbasid period, the empire became weakened due to which it started splinting into smaller states. This process of weakening of institution of the caliphate accelerated with the fall of the Abbasid Caliphate in Baghdad in 1258 AC. The Mamlukes, who had earlier established their own dynasty in Egypt, nominated one of the surviving Abbasid Prince as their Caliph. But he had no powers. Later, the Turkish warrior tribes founded the Ottoman Empire in some parts of Asia at the beginning of the fourteenth century and quickly extended it to other parts of Asia as well as the Europe. By the sixteenth century, they were able to include the entire Arabic speaking areas in Asia, North Africa (except Morocco) and South-Eastern Europe. Sultan Salim had conquered Egypt in 1517 AC and proclaimed himself as a first Ottoman Caliph (Khan, 1973: pp. 100-19; Tibi, 1997: pp. 76-81). 
The Ottomans occupied Egypt, captured caliphate and henceforth, the Nomadic warriors became the "protector of the faith" of the Ummah but their Mongolian conduct and wild nature never changed. They introduced the Law of Fratricide which gave sanction to the killings of brothers, uncles, nephews, sons, grandson, and even father of the one reaching to the throne on his turn. It was aimed to exterminate all prospective aspirants of the power or potential threats to the rule. Most regrettably, the text of such tyrannical law was supported by references to the Quran and the authority of the Ulema on the ground that the death of a "prince is less regrettable than the loss of a province." At the end of the sixteenth century, the draconian Law of Fratricide was replaced with an even more inhuman one. According to the newly introduced system of the Kafes (Cages), the children reaching to the age of 8 were taken to the Kafes, where they were likely to spend the whole of their lives without any pleasure of existence. Luckily, those inherited the throne, could reach to the court, but if they were deposed due to any reason, they were again sent to the Kafes. The said law was enforced till 1876 AC (Alderson, 1956; pp. 25-36). This was the picture of the "kind" and "just" conduct of the Ottomans to their own family members. The nature of their treatment of the subject people can also be understood from it.

The Ottoman Sultans, however, exploited Islamic universalism for the legitimacy of their despotic rule which gave "ideological sanction to their supra-national character of the Empire." Despite the exploitation of Muslims in the name of Islam, the Shariah was not enforced in true sense. The Islamists as well as young Ottomans, such as Namik Kemal and Ziya Pasha, shared the view that the Ottoman Empire declined because Shariah law was not truly observed. Thus, they relentlessly voiced for the complete enforcement and observance of Shariah for the regeneration of the empire. They demanded reforms based on Islamic injunctions of justice, shura, and equality of human beings (Tibi, 1997: p. 78; Rosenthal, 1965: pp. 28-47).

Even the foremost advocates of the caliphate conceded that the institution of the caliphate "in its last days" had become authoritarian and hallow. Due to authoritarian and despotic nature of the Ottoman Empire, Iqbal had supported the decision of the Turkish Grand National Assembly that caliphate was not necessarily needed to be vested in one person rather "it can be vested in a body of persons, an assembly or a parliament” (Khan, 1964-a: p. 2; Ahmad, 1970: pp. 68-70). Earlier, Ibn Taymiyyah had asserted that the caliph was not essential for the preservation of the faith. Instead, he gave importance to the Muslim community and not to an individual in the name of the caliphate. Both Ibn Taymiyyah and Allama Muhammad Iqbal, besides others support the idea of vesting the political power, not in one person, but to the Muslim community as a whole or their chosen representatives.

This principle was recognized and incorporated in the Objective Resolution passed by Pakistan's first constituent assembly in 1949. It was also included in the 1956 and 1973 constitutions of Islamic republic of Pakistan. The latter was particularly adopted after consultation with and with massive support of ulema and the leadership of main religious political parties of the country that shows their consensus on the subject. The constitution also declares Shariah as the supreme law of the state and provides various mechanisms for Islamization of existing laws. It mirrors the opinion of Ibn Taymiyyah that any state where Islamic law is supreme is an Islamic state. Any of the existing states in the Muslim world can declare Shariah as its supreme law and would become an Islamic state. 


\subsubsection{Is a Single Unified State Indispensable in Islam?}

Several Muslim jurists of earlier generations, as well Islamic scholars and religious leaders of the contemporary worlds believe that a single unified state encompassing all Muslims or at least all Muslim majority areas/states is essential as per Islamic injunctions. This perspective is bitterly opposed to contemporary political divisions of Muslims in scores of sovereign states. This view, however, is not free of fallacies and needs a critical examination. To address this crucial question, however, we need to look back into the Islamic history. The state of Madinah was formed by the general will of the organized community of believers transcending the clans, the tribes, and the nations unrestricted by geographical location. Only the message of Allah was the cohesive force among the members of the community. In the course of time, however, the cohesive bond of common belief became weak and differences and divisions on political, sectarian, and racial basis stirred up in the Muslim community (Khan, 1973: p. 98).

In the beginning, politics and Islam were interlinked where the state was regarded as "the agent of religion," the caliph as the supreme political leader of the community as well as the executor of the Shariah. But by the middle of the third century Hijrah, the caliph became "extremely weak" and real power went into the hands of Amir al-umara'a who later proclaimed themselves as Sultan. As the caliph was required to be a Qurashite, a compulsion which some jurists including alMuwardi make, non-Qurashite usurpers, could not appropriate this title and retained caliph as the supreme authority, though theoretically. In fact, the Sultans occasionally used to install caliphs in exchange of issuance of letters of the delegation of powers to the former by the latter. The caliphs who were supposed to defend the religion and its followers would not even defend themselves. Under the shadow of Mamluke sultans, the caliphs virtually had no powers, influence, prestige, or respect among the people (Khan, 1973: pp. 100-19). Muslim jurists recognized this bitter reality, a few of them seem inclined to discard away the theory of Immamah or caliphate altogether. The perspective of Ibn Tahmiyyah is worth citing.

Ibn Taymiyyah, who had regarded the Umayyads and the Abbasids as the Kings and not the vicegerent of the Prophet of Allah (SWT) conceived this dualist theory as harmful to the Shariah. He was aware of the shaky foundations of the concept of ideal Khilafah or Imamah invented by the Muslim jurists. He considered it an "empty talk" which was neither "realistic nor practicable." For him, it was, therefore, "no idealism but mere opportunism." He was, in fact, in favour of discarding this theory but he also refrained from giving a new theory of state because there was no such demand "from the Shariah or from the circumstances of his time." He developed the notion of a fresh basis of solidarity, reflected in two forms, in the unity of faith and the language (Khan, 1973: pp. 100-19).

Ibn Taymiyyah emphasized the unity and integrity of the Ummah but did not regard a single unified state as essential for this purpose. He was aware of the realities of the time and, thus, stressed only on the ideological unity of the Muslims. It may be supra-territorial encompassing the whole globe but within it, there might exist more than one states. He believed that even if there is one state, which is practically not workable, "it cannot be co-extensive with the Ummah, until the whole world has entered the fold of Islam.... because if a part of the world remains non-Muslim it might contain within its Muslim minority groups" constituting the Muslim Ummah outside the 
jurisdiction of such a universal state. Nonetheless, he advocated establishment of the state by the Muslims, "otherwise the religion would disappear" (Khan, 1973: pp. 122-130). Ibn Taymiyyah, in fact, recognized the possibility of existence of Muslim minorities in non-Muslim states. He stressed them to not lose their identity in the majority and should endeavour to become superior to capture political power there. For him, the form and structure of the state are not so important but the enforcement of Shariah should be the primary objective.

Ibn Taymiyyah accepted the need of the authority of the ruler over Muslims, but he did not deem it essential as encompassing the entire Muslim people or areas merging them into a single political unit/state. In fact, he justified the juridical division of the Muslim world into more than one states as he mentioned "rulers" and "sovereigns" etc. For him, authority can take any suitable shape and there could "be a number of independent Muslim states." He cited many traditions in support of his ideas. He was in favour of the necessity of law and order and strong government. Therefore, he thought that Muslims "should form independent states wherever feasible." These states must, however, make Shariah as the state law, and when they all adopt it, they would "ultimately confederate and achieve the unity of the Islamic Ummah." He stressed their confessional solidarity, where each state, maintaining its autonomy, had the "consciousness of being the member of an organic whole." For him, the ideal community is a confederation of states. He, therefore, did not endorse the idea of a single imam or caliph of a unified Islamic state comprising the whole Islamic world. For him, there may be "as many independent and sovereign imams as the exigencies of time and place require" (Khan, 1973: pp. 122-130).

Islam does not prohibit the existence of more than one Muslim state created based on exigencies of the time. These states can be formed on any basis which may deem necessary and feasible to the people. These can also be on a territorial basis. Historically too, there were the Muslim Empires established simultaneously in the name of Abbasid Caliphate, Fatimid Caliphate, and Umayyad Caliphate functioning in West Asia, Egypt (Africa), and Spain (Europe), respectively. These three Empires were formed and maintained based on the force of tribal asabiyya complementing religious zeal. This also provides a rationale for creation and the existence of the nation-states in the Muslim world. But before going ahead, it is imperative to know little bit about the western concept of the nation-state.

\subsection{What is a Nation State?}

A nation-state, in theory, assumes that everyone living therein belongs to the same nation - a group of people from the same area of origin who share a common history, culture, tradition, and language. It is a state whose population shares a sense of national identity, usually including common language and culture and sometimes also the religion. Mostly, it is a state with a single predominant national identity. The nation includes individuals whose common identity creates a psychological bond and a political community. Hans J. Morgenthau (1962: p. 60) says, "The nation needs a state. 'One nation - one state' is thus the political postulate of nationalism; the nation-state is its ideal." He maintains that "[t]he nation is the ultimate point of reference for political loyalties and actions... Nationalism wants one nation in a state and nothing else. Palmer \& Perkins (1998: pp. 5-11) describes nationalism as the ideology which holds the nation and the state together. It takes many forms but often involves a semi-mystical attachment to the "homeland." "Nationalism 
is the psychological or spiritual quality, which, although it may involve some earthy consequences, unites the people of a state and gives them the will to champion what they regard as their national interests." Wittkopf notes that nation-state "implies a convergence between territorial states and the psychological identification of people within them" (1987: pp. 39-40).

The present state system was introduced in 1648 with the Peace of Westphalia and was extended to the rest of the world with the emergence of new political units in Latin America, Asia, and Africa in the nineteenth and twentieth centuries. Theoretically, these states have the same rights as enjoyed earlier by the Western imperial powers i.e., territorial inviolability, freedom to conduct foreign relations, make treaties, and establish alliances with other states. Besides, they had the authority to establish "whatever" form of government they think best and to rule over their people. The concept of sovereignty - that no one is above the state - captured the central position in these legal rights (Jackson \& Sorensen, 1999).

\subsection{Nationalism and Islam}

What is the origin of nationalism? Generally, scholars view nationalism as a Western concept or idea that originated in the modern period. This perspective, however, is not true. Sehmi (1983) rightly noted that the origin of modern nationalism cannot be attributed as a contribution of any single country or civilization in terms of time or locale or both, because of an outcome of its sociopolitical evolution of centuries in Europe. In fact, the seeds of nationalism can be traced back to remote past. One of the factors that motivated great warriors and conquerors of the ancient times for world conquest was their thirst of national pride which is key attribute of nationalism. The ancient Greek language word barbaros (alien or stranger) or the Arabic word ajjam (dumb) and of Sanskrit expression babara (stammering) were the symbols of expression of their tribal or national superiority over others. Nationalism represents unity based on religion, language, race, traditions, territory, culture, and customs. "It is a frame of mind, a life-attitude, and a character orientation. National character is a sum of all or most of the members comprising a large group compactly living in its habitat" (pp. 1-10).

Islam does not recognize castes, creeds, races, or colour of the people as an element of precedency or superiority over others. It rejects divisions on the name of race, culture, and geography. It rather promotes and encourages the concept of the unity of humanity. Holy Prophet cut across all racial and linguistic distinctions declaring that all human being are brothers. He re-affirmed it while saying, "You all are children of Adam and Adam was made of clay" (Ahmad, 1970: pp. 68-70; Khan, 1964-a: p. 8). Chaudhry quotes Iqbal as saying that it was "Islam which first gave the message to mankind that religion is neither national nor racial, neither personal nor private, but purely human. Its aim, despite all-natural differences, is to unify and discipline the whole humanity" (Chaudhry, 1996: p. 500). Meanwhile, Islam does not reject the existence of tribes and races and gives them legitimacy as symbols of identity. According to Quran (49: 13) people are divided into tribes and races and communities for their identification. It is also a fact that the hundreds of thousands of Messengers (Prophets) of Allah were "commissioned" to their respective nations. Even their names have been mentioned in the Holy Quran along with their respective nations. Moreover, the word Ummah meaning nation, or its synonyms, has been often used in the Holy Quran (Sehmi, 1983: p. 224). 
Even at the time of the establishment of the state at Madinah the identity of different tribes was not only recognized but they were also given autonomy in their respective tribal jurisdiction in many ways. The Charter of Madinah $(\mathrm{CoM})$ refers to the respective tribes mentioning their rights and duties. It provides that the Muhajireen-e-Makkah belonging to the Quraish, as well as five groups forming the Khazraj and three groups forming the Aws, will preserve their respective tribal constitution and continue to follow their customs regarding paying blood-wits and redeeming their own prisoners. The Charter also recognizes Jews as a part of Ummah with certain conditions. Brohi observes that the Charter of Madinah did not make any meaningful change in judicial and executive norms already prevailing in the respective tribes. Hence a "confederated type" of government was established in Madinah (Brohi, 1982: pp. 81-2). This fact affirms that CoM provided the basis for a federal, not unitary, state. Raza Rabbani, former Chairman Senate of Pakistan also holds the view that the state of Madinah was modelled on federal lines as reflected in CoM signed between three communities; Muhajireen, Ansar and Jews of Madinah; all living together peacefully and enjoying equal rights (Rabbani, 2010: p. ix).

The State of Madinah as established by the Holy Prophet (PBUH) was based on a social contract i.e., the CoM, agreed by the people from various tribes living in city of Madinah. It was confederation or federation of tribes in which different tribes enjoyed considerable autonomy. However, when the state was expanded due to conquests, it was increasingly centralized. When caliphate was converted into monarchy, it accompanied centralization of powers which were converged into the hands of a single person, i.e., caliph. It was, however, a deviation from the foundations on which state of Madinah was formed. Autonomy of constituent units (tribes in this case) and federal character based on a written constitution/contract were the hallmarks of the state of Madinah.

During the early days of Islamic integration, tribalism could not be fully eradicated and somehow it became an added force with Islam. Even the system of financial distribution during the conquest was based on tribal lineage (dabt al-ansab). However, it was not free of tensions. As Ayubi noted that the "tribal asabiyya" invoked the conflict between Ali and Mu'awiya (Ayubi, 1991: p. 9). Tribal asabiyya also provided group unity and cohesion that also played significant role in rise and fall of dynasties. Ibn Khaldun's theory of asabiyya explains the cohesiveness of a human group, such as tribes, and people. He asserts that each group develops from a state of a nomadic society towards a civilized one and leads towards the formation of a state. For Ibn Khaldun, asabiyya plays a significant role in the formation and disintegration of states. He explains that when asabiyya is strong states and dynasties are formed. But asabiyya, as group solidarity of the nomadic people loses its vigour and cohesiveness with the passage of time. When the group members live easy lives, they become weaker, and their states eventually fall. For Ibn Khaldun, asabiyya translates the will of the people into reality with the effective support of like-minded people held together by a common bond. This bond is in the first place, based on kinship, blood relations and family ties that create a sense of solidarity, mutual respect, sense of responsibility, and common outlook leading to a united action and serving as a driving force in the formation of dynasties (Ayubi, 1991: p. 22; Rosenthal, 1988: pp. 84-109).

One can make a relationship between asabiyya and nationalism on be the basis of the above explanation. The first place of asabiyya as a bond is a family and ties of blood if accepted, and 
then it must gradually and increasingly go passing through clan and tribe to the nation and nationalism. In fact, many persons compose a family, many families form a clan, many clans make a tribe, many tribes constitute an ethnic group, and many ethnic groups give birth to a nation. Various European writers translated Ibn Khaldun concept of Asabiyya with group solidarity, but some others interpreted it as a concept of nationalism. Sati al-Husri, a prominent advocate of Pan Arabism accepted the second line. He explains asabiyya, as the sociability of men expressed in a national bond. Tibi claims that for Ibn Khaldun, "religion cannot replace asabiyya" however, "asabiyya finds its highest expression in a synthesis with religion, but in such a synthesis religion takes on the quality of a national religion." Arab nationalists are much inspired by Ibn Khaldun, and they present him as an example to Europeans claiming that the Arabs have produced such ideas much before them (Tibi, 1997: pp. 138-41). On the same ground, Michel Aflaq contends that Arab nation is an eternal nation, as old as history. Tibi suggests that the idea of Arab Nationalism is related to the overall history as "to a continuation of a traditional Arab asabiyya," and cannot be restricted to the impact of the west (Tibi, 1997: p. 10).

Meanwhile, Muslim dynasties generally became popular or known with their tribal extraction tracing their origin back to ancestors. For instance, Umayyad dynasty is known as such because the rulers belonged to the tribe of Banu Umayyad, Abbasid dynasty belonged to Banu Abbas, and the Ottoman Empire belonged to the successors of Uthman. Similarly, the dynasties of Seljuks, Mamlukes, Fatimids, Mughals, and Khiljis besides others are known with the name of their clan, tribe, or ancestral background. It is also worth mentioning that various companions of the Prophet Mohammad (PBUH) used their surnames after the name of their areas/places of origin/birth, e.g., Farsi, Habashi, etc. The Holy Prophet did not object them. This trend has also been followed by leading religious scholars including Imam Bukhari, whose Book's title also reflects his being from Bukhara. Many jurists take the position that Caliph could only be from the tribe of Quraish. As Tibi noted, "the caliphate, according to Islamic orthodoxy, is reserved to members of the tribe of Quraish, from which Mohammad came." Many Arabs including religious personalities like Muhammad Bin Abd Wahab and Sharif Hussain of Makkah, challenged the legitimacy of Ottomans as caliphs on the same ground. For the same reason, Ottomans tried to "legitimize their rule by using historians in the court to make up lineage for the sultans, tracing their Arab origin back" to the Prophet Mohammad (Tibi, 1997: pp. 78-90).

Many Arab nationalists attach superiority of Arabic language - as a language of Islam, over other languages and try to equate Arabism with Islam. In fact, theologians like Ibn Taymiyyah could not refrain from arguing the superiority of the Arabic languages over other languages. Though he did not ask to destroy other languages, he supported the imposition of Arabic as the state language in all the Muslim lands. For him it is the only one which is a language of religion, a symbol of Islam and its followers and it alone can "reduce political difference and maintain the solidarity of the Ummah" (Khan, 1973: pp. 100-19). In sum, the nation signifies a group identity as do a family, clan, tribe, or an ethnic group. National pride and nationalism are naturally associated with the idea of a nation that one cannot and should not negate or discard away perceiving it as Western concepts or ideas. Islam accepts and accommodates such natural feelings of love and attachment with one's group identity that can also be used for uniting people together to achieve any objectives including national emancipation and state formation. 


\section{Conclusion}

Quran and Sunnah do not prescribe any fixed form of system or structure of the state. Islam, as a dynamic and progressive religion for all times and all people, left the door open for the believers to adopt any system or form of government which they deem necessary according to the requirements of the time. Contrary to the conventional Muslim political thoughts, caliphate is neither pillar of faith nor requirement of Shariah. According to Ibn Taymiyyah, it is only a minor or secondary issue. Theorizing of the institution of the caliphate, by other jurists, was just aimed to bring legitimacy to the dying Muslim monarchies. Any state where Shariah is supreme is an Islamic state.

Islam does not ordain to establish a single unified Muslim state encompassing entire Muslim population of the world. In fact, it is not possible to create any such state. If somehow, all Muslim states merge together to form a single unified Muslim state, it would still be most likely that Muslim minorities living in non-Muslim states would be left out of its ambit. Thus, there is no restriction on the number of Islamic states. These may be formed according to the exigencies of time and place. However, Shariah must be preserved. These states may be formed on any basis, even on a territorial basis. Islam does not recognize castes, creeds, races, or colour of the people as a matter of distinction or superiority over others. At the same time, it also does not negate their existence. Rather it recognizes them as symbols of identity of the people.

As such nationalism that does not preach hate against others, seeks love, unity and brotherhood among co-members and makes people loyal to their land has no conflict with Islam. Thus, states can be created based on ethnicity or territorial nationalism. State of Madinah was established based on a social contract, CoM, agreed by the people from different tribes living in Madinah. It not only recognized separate identity of the tribes but also gave them (tribal) autonomy that signifies federal character of the state of Madinah. Centralization of powers took place when state expanded due to conquests, particularly after caliphate was transformed into monarchy. However, this unitary character of the state and concentration of powers into one person, either the caliph or sultan, besides hereditary rule was deviation from the foundations over which state of Madinah was formed. Autonomy of constituent units (tribes in this case) and federal character based on a written constitution/social contract were the hallmarks of the state of Madinah.

\section{References}

Ahmad, A. (1970). Studies in Islamic culture in the Indian environment, (reprint). Karachi: Civil \& Military Press.

Ahsan, R. (1964). The world commonwealth of Islam. In Motamar al-Alam al-Islami (Ed.), Studies on Commonwealth of Muslim Countries. Karachi: Umma Publishing House.

Alderson, A. D. (1956). The structure of the Ottoman dynasty. Oxford: The Clarendon. Ayubi, N. (1991). Political Islam: Religion and politics in the Arab world. London: Routlege.

Brohi, A. K. (1982). Islam: Its political and legal principals. In Salem Assam (Ed.), Islam and Contemporary Society. London: Longman. 
Chaudhry, M. A. (1996). Muslim political thought: A history of pre-Islamic period and Muslim political thought from mediaeval ages to modern times. Lahore: Publisher Emporium.

Haq, M. (1991). Political science: Theory and practice, $\left(8^{\text {th }}\right.$ ed.), Lahore: Bookland.

Jackson, R. \& Sorensen, G. (1999). Introduction to international relations. New York: Oxford University Press.

Kegley, C. W. Jr. \& Wittkopf, E. R. (1987). World politics: Trends and transformation (6 ${ }^{\text {th }}$ ed.), New York: St. Martin's Press.

Khan, I. (1964). Introduction. In Motamar al-Alam al-Islami (Ed.), Studies on Commonwealth of Muslim Countries. Karachi: Umma Publishing House.

Khan, I. (1964). Some thoughts on the idea of a commonwealth of Muslim countries. In Motamar al-Alam al-Islami (Ed.), Studies on Commonwealth of Muslim Countries. Karachi: Umma Publishing House.

Khan, N. A. (1964). A commonwealth of Muslim states. In Motamar al-Alam al-Islami (Ed.), Studies on Commonwealth of Muslim Countries. Karachi: Umma Publishing House.

Khan, Q. (1973). The political thought of Ibn Taymiyah. Islamabad: Islamic Research Institute.

Maududi, S. A. A. (1981). A short history of the revivalist movement in Islam. Al-Ash'ari, (trans.), $5^{\text {th }}$ ed. Lahore: Islamic Publications Limited.

Morgenthau, H. J. (1962). Politics among nations ( $3^{\text {rd }}$ ed.), New York: Alfred A Knopf.

Palmer, N. D. \& Perkins, H. C. (1998). International relations, (3 ${ }^{\text {rd }}$ ed.), New Delhi: A.I.I.B.S.

Pew Research Centre (2009, October 7). Mapping the global Muslim population. Retrieved from https://www.pewforum.org/2009/10/07/mapping-the-global-muslim-population/\#map2

Rabbani, M. R. (2010, December). Preface. In Zubair Faisal Abbasi, Federalism, Provincial autonomy, and conflicts. Islamabad: Centre for Peace and Development Initiatives.

Rosenthal, E. I. J. (1965). Islam in the modern national state. Cambridge: Cambridge University Press.

Rosenthal, E. I. J. (1988). Political thought in medieval Islam: An introductory outline. Cambridge: Cambridge University Press.

Sehmi, A. H. (1983). Nationalism, Islam and Pakistan. Lahore: Islamic Publications.

Sherwani, H. K. (1997). Studies in Muslim political thought and administration. Lahore: Ashraf Printing Press.

Tibi, B. (1997). Arab nationalism: Between Islam and the nation state, (3 ${ }^{\text {rd }}$ ed.), London: Macmillan Press. 